\title{
Analisis Bahan Pencemar Dominan di Muara Way Tomu Dan Muara Way Lela Wilayah Pesisir Kota Ambon
}

\author{
Analysis of Pollutants Dominant in Muara Way Tomu and Muara Way Lela Coastal Ambon City
}

Yosias Marthen Pesulima, Pieter J. Kunu* dan Adelina Siregar

Jurusan Budidaya Pertanian, Fakultas Pertanian, Universitas Pattimura

Jl. Ir. M. Putuhena, Kampus Poka, Ambon 97233

*Penulis korespondensi: e-mail: pieterkunu@gmail.com

\begin{abstract}
The aims of this research are to find the dominant pollutants in estuarine of Way Tomu and Way Lela, determine the water quality in the estuary Way Tomu and Way Lela, and comparing the effects of the density of settlement on water quality of estuary Way Tomu and Way Lela. The research was conducted in October until November 2015. The method used was survey method with variables the physical parameters (Total Dissolved Solid, Total Suspended Solid, temperature), chemicals parameter (detergents, nitrate, nitrite, $\mathrm{pH}, \mathrm{BOD}, \mathrm{COD}, \mathrm{DO}$, amonia, phosphate, iron, oil and fat, manganese, coopper) and biology parameter (E. coli) class II. The result showed that the dominant chemicals parameter and affect water quality in the Way Tomu is Detergent $(746 \mathrm{mg} / \mathrm{L})$, while for the Way Lela estuary are detergent $(835 \mathrm{mg} / \mathrm{L})$, phosphate $(0,4631 \mathrm{mg} / \mathrm{L})$, and dissolved oxygen $(3,2 \mathrm{mg} / \mathrm{L})$, and biological parameters i.e., E. coli. These values have exceeded the value of the quality standard of the water quality is appropriate Government Regulation Number 82 the Year 2001 about Water Quality Management and Control of Water Pollution Classes II. It is thought to be due to the behavior of the people who live the area of the riverbanks of Way Lela and Way Tomu that their household trash into the river. For that is a need for the attention of the Government and local communities to improve the quality of the river water in the Way Tomu and Way Lela with improving the environment-friendly behavior.
\end{abstract}

Keywords: pollutants, pollution estuary, way Tomu, way Lela

\begin{abstract}
ABSTRAK
Tujuan dari penelitian ini adalah untuk menemukan polutan yang dominan di muara Way Tomu dan Way Lela; menentukan kualitas air di muara Way Tomu dan Way Lela; serta membandingkan efek dari kepadatan pemukiman terhadap kualitas air muara Way Tomu dan Way Lela. Penelitian ini telah dilakukan pada bulan Oktober sampai November 2015. Metode yang digunakan adalah metode survei dengan variabel penelitian berupa parameter fisik (Total Dissolved Solid, Total Suspended Solid, suhu), parameter kimia (deterjen, nitrat, nitrit, pH, BOD, COD, DO, amonia, fosfat, besi, minyak, dan lemak, mangan, tembaga) dan parameter biologi (E. coli) kelas II. Hasil penelitian menunjukan bahwa parameter kimia yang dominan dan mempengaruhi kualitas air di muara Way Tomu adalah Deterjen $(746 \mathrm{mg} / \mathrm{L})$ sedangkan untuk muara Way Lela adalah Deterjen $(835 \mathrm{mg} / \mathrm{L})$, Fosfat $(0,4631 \mathrm{mg} / \mathrm{L})$, dan Oksigen terlarut $(3,2 \mathrm{mg} / \mathrm{L})$, serta parameter biologi yaitu E. coli. Nilai-nilai ini telah melampaui nilai baku mutu kualitas air Sesuai Peraturan Pemerintah Nomor 82 Tahun 2001 tentang Pengelolaan Kualitas Air dan Pengendalian Pencemaran Air Kelas II. Hal ini diduga sebagai akibat perilaku masyarakat yang tinggal di daerah bantaran Way Tomu dan Way Lela yang membuang limbah rumah tangga ke sungai. Untuk itu perlu adanya perhatian pemerintah dan masyarakat setempat untuk memperbaiki kualitas air sungai di Way Tomu dan Way Lela dengan meningkatkan perilaku ramah lingkungan.
\end{abstract}

Kata Kunci: bahan pencemar, pencemaran muara sungai, way tomu, way lela

\section{PENDAHULUAN}

Air merupakan sumber daya alam yang memenuhi hajat hidup orangbanyak sehingga perlu dilindungi agar dapat bermanfaat bagi hidup dan kehidupan manusia serta mahkluk hidup lainnya. Untuk menjaga atau mencapaikualitas air sehingga dapat dimanfaatkan secara berkelanjutan sesuai dengantingkat mutu air yang diinginkan, maka perlu upaya pelestarian dan pengendalian. Pelestarian kualitas air merupakan upaya untuk memelihara fungsi air agar kualitasnya tetap pada kondisi alamiah. Pengelolaan kualitas air dilakukan 
dengan upaya pengendalian pencemaran air, yaitu dengan upaya memelihara fungsi air sehingga kualitas air memenuhi baku mutu.

Pencemaran air yaitu masuknya mahluk hidup, zat, energi ataukomponen lain ke dalam air, sehingga kualitas air turun sampai ke tingkat tertentu yang menyebabkan air tidak berfungsi lagi sesuai dengan peruntukannya. Menurut Kristanto (2002), pencemaran air adalah penyimpangan sifat-sifat air dari keadaan normal. Air dapat tercemar oleh komponen-komponen anorganik, diantaranya berbagai logam berat yang berbahaya. Komponen-komponen logam berat ini berasal dari kegiatan industri. Kegiatan industri yang melibatkan penggunaan logam berat antara lain industri tekstil, pelapisaan logam, cat/tinta warna, percetakan, bahan agrokimia, dan lain-lain. Beberapa logam berat ternyata telah mencemari air, melebihi batas yang berbahaya bagi kehidupan (Wisnu, 1995).

Limbah domestik yang paling dominan adalah jenis organik yang berupa kotoran tinja dan hewan. Jenis limbah domestik yang lain adalah limbah domestik anorganik yangdiakibatkan oleh plastik serta penggunaan deterjen, sampho, cairan pemutih, pewangi dan bahankimia lainnya. Limbah domestik jenis ini relatif lebih sulit untuk dihancurkan. Jika kuantitas dan intensitas limbah domestik ini masih dalam batas normal, alam masih mampu melakukan proses kimia, fisika, dan biologi secara alami. Namun, peningkatan populasi manusia telah menyebabkan peningkatan kuantitas dan intensitas pembuangan limbah domestik sehingga membuat proses penguraian limbah secara alami menjadi tidak seimbang dan terjadi secara terus menerus (Soemarwoto, 1991).

Dewasa ini, pencemaran sungai menjadi masalah yang memerlukan perhatian serius. Untuk mendapat air bersih sesuai standar baku mutu sudah cukup sulit untuk didapatkan. Hal ini dikarenakan air sungai yang selalu menjadi sumber air bagi kebutuhan masyarakat telah tercemar oleh berbagai macam limbah aktivitas manusia di sekitar sungai, dan menyebabkan menurunnya kualitas air sungai itu sendiri.

Pencemaran sungai di Kota Ambon yang terjadi beberapa tahun belakangan ini sudah merupakan salah satu masalah serius yang sering ditemui di lapangan. Adanya masukan bahan pencemar ke sungai mengakibatkan penurunan kualitas air. Bahan pencemar yang masuk tersebut berasal dari pembuangan limbah kegiatan domestik yang akan mengakibatkan meningkatnya pencemaran di sungai khususnya pada muara-muara sungai.

Pembangunan di Kota Ambon pada beberapa tahun ini sudah semakin pesat sehingga muncul berbagai masalah lingkungan, dimana perkembangan Kota yang semakin pesat dengan bertambahnya berbagai fasilitas Kota, bertambahnya penduduk dan makin banyaknya daerah-daerah permukiman maka kebutuhan dari masyarakat sendiri akan semakin meningkat dan akan memicu tingginya penggunakan bahan pencemar yang bukan saja mencemari lingkungan di darat melainkan di sungai (air).
Muara Way Tomu dan Way Lela merupakan muara sungai yang masuk dalam wilayah Kota Ambon, muara Way Tomu melintas di Kelurahan Honipopu dan muara Way Lela melintas di Kelurahan Rumah Tiga Kota Ambon, dimana kedua sungai ini sudah menjadi tempat aktivitas masyarakat dan tempat alternatif dalam membuang sampah. Pertambahan jumlah pemukiman yang semakin banyak dari tahun ke tahun di kedua muara ini dengan luas lahan yang tetap, mengakibatkan tekanan terhadap lingkungan semakin berat. Berbagai aktivitas manusia dalam memenuhi kebutuhan hidup yang berasal dari kegiatan industri, rumah tangga, dan pertanian juga akan menghasilkan limbah yang memberi dampak pada penurunan kualitas air sungai (Suriawiria, 1986).

Di kota Ambon pencemaran sungai akibat aktivitas dari masyarakat pada saat sekarang semakin tinggi, limbah-limbah rumah tangga semuanya dibuang ke badan-badan sungai. Titaley (2014), menemukan parameter kimia (amonia $\left(\mathrm{NH}_{3}\right.$ dan $\left.\mathrm{COD}\right)$ dan parameter fisik (bau), sudah melampaui baku mutu yang ditetapkan menurut Peraturan Pemerintah No. 82 (2001) tentang Pengelolaan Kualitas Air dan Pengendalian Pencemaran Air Kelas II, yang mengakibatkan menurunnya kualitas air Way Tomu. Hal ini menunjukkan semakin bertambah kepadatan permukiman maka semakin bertambah pula volume sampah yang dibuang ke badan sungai khususnya di muara.

Berdasarkan uraian latar belakang di atas maka perlu penelitian, berjudul "Analisis Bahan Pencemar Dominan di Muara Way Tomu dan Muara Way Lela Wilayah Pesisir Kota Ambon" untuk menemukan bahan pencemar dominan pada muara Way Tomu dan muara Way Lela di Wilayah Pesisir Kota Ambon, menetapkan kualitas air Way Tomu dan Way Lela akibat bahan pencemar dan membandingkan pengaruh kepadatan permukiman terhadap kualitas air muara Way Tomu dan muara Way Lela.

\section{METODE PENELITIAN}

\section{Jenis Penelitian}

Penelitian ini merupakan penelitian survey yaitu pengamatan dilakukan langsung di lapangan dan pengumpulan data sosial dan desk analysis serta analisis laboratorium terhadap sampel air sungai yang diambil pada muara sungai Way Tomu dan Way Lela.

\section{Tempat dan Waktu Penelitian}

Penelitian ini dilaksanakan di dua sungai yakni di muara Way Tomu dan muara Way Lela Kota Ambon, dari bulan Oktober sampai November 2015.

\section{Alat dan Bahan}

Alat yang digunakan dalam penelitian ini antara lain; currentmeter, alat tulis menulis, kamera digital, meter roll $50 \mathrm{~m}$, kayu pengukur kedalaman 
aliran sungai, pelampung, tali arafia. Bahan penelitian yang digunakan adalah: air sungai, kuesioner, botol sampel, google maps.

\section{Ruang lingkup penelitian}

Maluku sebagai salah satu provinsi kepulauan, terdiri atas 1400 pulau yang didominasi oleh pulaupulau kecil dan didominasi oleh topografi yang umum berupa bukit dan gunung sehingga DAS yang terbentuk juga umumnya berukuran kecil dan pendek. Kondisi ini memungkinkan curah hujan yang jatuh ke atas DAS sangat cepat mengalir dan memasuki kawasan perairan.

Kondisi pulau yang kecil tersebut juga telah menyebabkan penggunaan lahan untuk permukiman masyarakat dibuat hingga dari bantaran-bantara sungaisampai ke punggung-punggung bukit dan gunung hingga ke arah hulu DAS.

\section{Prosedur Penelitian}

Penilaian kualitas air sungai yang dikaji didasarkan pada kriteria baku mutu kualitas air menurut Peraturan Pemerintah Nomor 82 Tahun 2001 tentang Pengelolaan Kualitas Air dan Pengendalian Pencemaran Air Kelas II. Selanjutnya untuk mengetahui konsepsi masyarakat tentang pencemaran air dan perilaku masyarakat terhadap sampah dan pencemaran sungai dilakukan dengan teknik wawancara dengan penduduk yang bermukin di sekitar bantaran sungai di muara Sungai Way Tomu dan Way Lela.

Tahap Persiapan: Tahapan persiapan mencakup, persiapan alat dan bahan yang digunakan dan survei lokasi penelitian. Tahap Pelaksanaan di Lapangan: a) Pengukuran debit aliran sungai dengan menggunakan currentmeter dan b) Penetapan titik pengamatan di lapangan dengan jumlah titik yang representatif di setiap muara sebanyak empat titik pengamatan dan pengambilan sampel kemudian dikomposit untuk kebutuhan analisis di laboratorium.

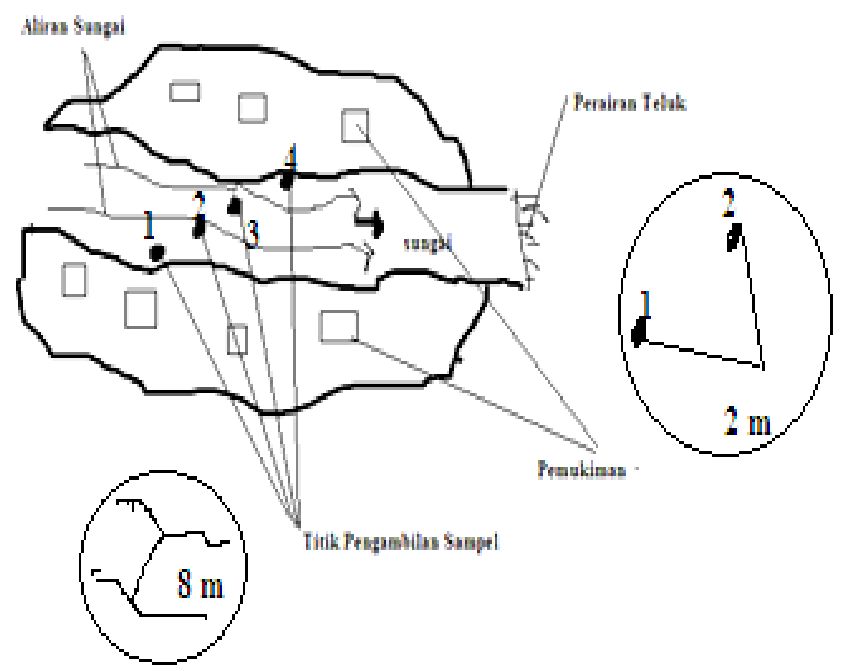

Gambar 1. Denah titik pengambilan contoh air di muara

\section{Pengambilan Sampel Air Sungai}

Pengambilan sampel air dilakukan pada dua muara Tomu dan muara Way Lela wilayah pesisir Kota Ambon, dilakukan pada empat titik pengamatan di setiap sungai yang telah ditentukan dan dikomposit. Pengambilan sampel dilihat berdasarkan dua faktor diantaranya: a) berdasarkan jam-jam aktivitas masyarakat: Sampel air dari muara sungai yang diamati diambil waktu berbeda yaitu, Waktu siang (pukul 06.0009.00, 12.00-14.00 dan 17.00-22.00 WIT), Waktu malam (pukul 00.00-05.00 WIT). Sampel air diambil setiap jam pada empat titik pengamatan yang telah ditentukan dan dikomposit; dan b) berdasarkan hari aktivitas masyrakat: Hari aktivitas masyarakat dibagi menjadi dua hari yakni, hari libur (minggu) dan hari kerja (senin). Sampel air diambil pada empat titik pengamatan yang telah ditentukan dan dikomposit. Sampel air yang diambil di muara sungai di isi ke dalam botol sampel kemudian dianalisis di Balai Teknik Kesehatan Lingkungan Ambon untuk mengetahui kualitas air sungai pada muara Way Tomu dan muara Way Lela yang mana dilihat kualitas air secara fisik, kimia dan biologi sesuai standar analisis menurut Greenberg (1995). Hasil analisis air sungai akibat pencemaran kemudian dibandingkan dengan baku mutu air menurut Peraturan Pemerintah No. 82 (2001) dan dilihat bahan pencemar dominannya.

\section{Pengukuran parameter}

Parameter yang diamati dalam penelitian ini yaitu parameter fisik kualitas air (TDS, TSS, suhu), kimia (deterjen, nitrat, nitrit, $\mathrm{pH}, \mathrm{BOD}, \mathrm{DO}$, amonia, fosfat, besi, minyak dan lemak, mangan, tembaga) dan biologi (E. coli) yang dibandingkan dengan Peraturan Pemerintah No. 82 (2001) tentang Pengelolaan Kualitas Air dan Pengendalian Pencemaran Air Kelas II.

\section{Analisis Data}

Analisis data yang dilakukan yaitu hasil analisis laboratorium Balai Teknik Kesehatan Lingkungan Ambon untuk sampel air yang dibandingkan dengan standar baku mutu air kelas II menurut Peraturan Pemerintah No. 82 (2001), untuk mengetahui kualitas air muara Way Tomu dan muara Way Lela dan polutan dominan pada kedua muara.

\section{HASIL DAN PEMBAHASAN}

\section{Keadaan Umum Lokasi Penelitian}

\section{Letak dan Batas Daerah Penelitian}

Penelitian ini dilakukan pada dua aliran sungai yang ada di Kota Ambon yaitu sungai Way Tomu yang secara administrasi termasuk dalam wilayah Kecamatan Sirimau Kelurahan Honipopu Kota Ambon sedangkan sungai Way Lela termasuk dalam wilayah Kecamatan Teluk Ambon Kelurahan Rumah Tiga Kota Ambon. 
Penelitian ini dilakukan pada dua aliran sungai pada muara sungai (hilir).

Secara geografis daerah aliran sungai Way Tomu dibatasi sebelah utara dengan DAS Batu Merah, di sebelah selatan dengan DAS Batu Gajah dan di sebelah Timur dengan pantai (Teluk Ambon). Sedangkan daerah aliran sungai Way Lela dibatasi sebelah utara dengan DAS Way-Pia Kecil, disebelah selatan dengan Desa Poka Tengah dan disebelah Timur dengan Pantai (Teluk Ambon).

Keadaan topografi daerah penelitian muara Way Tomu dan Way Lela relatif datar, karena hampir sebagian besar muara-muara suatu sungai memiliki keadaan topografi berbentuk datar. Muara dari DAS Way Tomu ini sendiri berada pada daerah Kota Ambon sedangkan muara dari DAS Way Lela sendiri berada pada Desa Rumah Tiga. Limbah domestik yang dihasilkan oleh penduduk di sekitar muara Way Tomu dan muara Way Lela secara umum berasal dari aktivitas pemukiman, rumah makan, dan perkantoran.

Kedua muara sungai yamg dijadikan sebagai tempat penelitian berada pada muara Way Tomu dan muara Way Lela, pada setiap muara sungai diberikan empat titik pengambilan sampel air yang kemudian dikomposit, hal ini dapat dilihat pada Gambar 2.

\section{Karakteristik Penduduk}

Karakteristik penduduk di kelurahan Honipopu dan kelurahan Rumah Tiga dilihat berdasarkan jumlah penduduk, dimana jumlah penduduk Kelurahan Honipopu adalah 6.453 jiwa dan untuk jumlah penduduk pada Kelurahan Rumah Tiga adalah 9.235 jiwa.

\section{Karakteristik Responden}

Responden yang menjadi sampel dalam penelitian ini adalah penduduk sekitar muara sungai Way Tomu dan muara sungai Way Lela. Untuk muara digunakan 20 responden sehingga jumlah responden dalam penelitian ini adalah 40 responden. Karakteristik responden dalam penelitian adalah sebagai berikut:

\section{(1) Komposisi Umur Responden}

Dalam penelitian ini, responden yang diwawancarai berumur 25-65 tahun. Jumlah responden paling banyak adalah yang berumur antara 45-54 tahun (35\%) dan paling sedikit adalah yang berumur lebih dari 65 tahun (5\%). Secara rinci karakteristik responden berdasarkan umur dapat dilihat pada Tabel 1 .
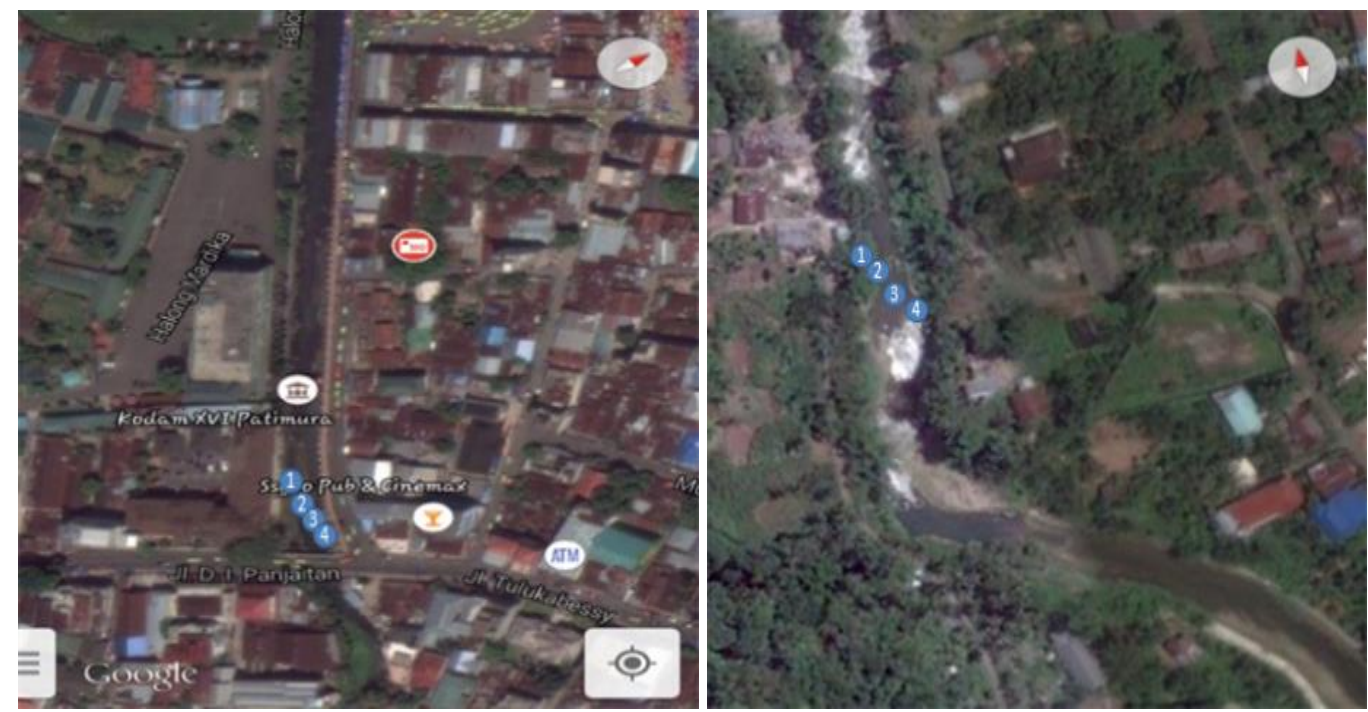

Gambar 2. a) Muara Way Tomu; dan b) Muara Way Lela

Tabel 1. Komposisi umur responden

\begin{tabular}{ccccccc}
\hline \multirow{2}{*}{$\begin{array}{c}\text { Umur } \\
\text { (Tahun) }\end{array}$} & \multicolumn{2}{c}{ Lokasi } & \multicolumn{2}{c}{ Total } \\
\cline { 2 - 5 } & \multicolumn{2}{c}{ Muara Way Tomu } & \multicolumn{2}{c}{ Muara Way Lela } & Jumlah & $(\%)$ \\
Jumlah orang & $(10 \%)$ & Jumlah orang & $(\%)$ & $(15 \%)$ & 5 & $(12,5 \%)$ \\
\hline $25-34$ & 2 & $(30 \%)$ & 4 & $(20 \%)$ & 10 & $(25,0 \%)$ \\
$35-44$ & 5 & $(35 \%)$ & 6 & $(30 \%)$ & 13 & $(32,5 \%)$ \\
$45-54$ & 7 & $(25 \%)$ & 5 & $(20 \%)$ & 10 & $(25,0 \%)$ \\
$55-64$ & 5 & $(5 \%)$ & 2 & $(10 \%)$ & 3 & $(7,5 \%)$ \\
65 ke atas & 1 & $(100 \%)$ & 20 & $(100 \%)$ & 40 & $(100 \%)$ \\
\hline Total & 20 & & & & &
\end{tabular}

Sumber: Data Penelitian (2015) 
Tabel 2. Karakteristik responden menurut tingkat Pendidikan

\begin{tabular}{lcccccc}
\hline \multirow{2}{*}{ Pendidikan } & \multicolumn{3}{c}{ Lokasi } & \multicolumn{2}{c}{ Total } \\
\cline { 2 - 5 } & \multicolumn{2}{c}{ Muara Way Tomu } & \multicolumn{2}{c}{ Muara Way Lela } & \multicolumn{2}{c}{$(\%)$} \\
\cline { 2 - 6 } Tidak Sekolah & Jumlah Orang & $(\%)$ & Jumlah Orang & $(\%)$ & Jumlah Orang & $(\%)$ \\
SD & 0 & $(0 \%)$ & 0 & $(0 \%)$ & 0 & $(0 \%)$ \\
SMP & 0 & $(10 \%)$ & 4 & $(20 \%)$ & 6 & $(15 \%)$ \\
SMA & 2 & $(60 \%)$ & 11 & $(55 \%)$ & 23 & $(57 \%)$ \\
D1-D3 & 12 & $(5 \%)$ & 0 & $(0 \%)$ & 1 & $(2,5 \%)$ \\
S1-S2 & 1 & $(25 \%)$ & 3 & $(15 \%)$ & 8 & $(20 \%)$ \\
\hline Total & 5 & $(100 \%)$ & 20 & $(100 \%)$ & 40 & $(100 \%)$ \\
\hline
\end{tabular}

Sumber: Data Penelitian (2015)

Tabel 3. Karakterisitik responden berdasarkan jumlah anggota keluarga

\begin{tabular}{lcccccc}
\hline \multirow{2}{*}{ Jumlah Anggota Keluarga } & \multicolumn{4}{c}{ Lokasi } & \multicolumn{2}{c}{ Total } \\
\cline { 2 - 5 } & \multicolumn{2}{c}{ Muara Way Tomu } & \multicolumn{2}{c}{ Muara Way Lela } & Jumlah & $(\%)$ \\
\cline { 2 - 5 } & Jumlah orang & $(\%)$ & Jumlah Orang & $(\%)$ & $(35)$ & $(37,5 \%)$ \\
\hline Kurang dari 4 orang & 7 & $(35 \%)$ & 8 & $(40 \%)$ & 15 & $(52,5 \%)$ \\
4-6 orang & 10 & $(50 \%)$ & 11 & $(55 \%)$ & 21 & $(10 \%)$ \\
7-9 orang & 3 & $(15 \%)$ & 1 & $(5 \%)$ & 4 & $(10 \%)$ \\
Lebih dari 9 orang & 0 & $(100 \%)$ & 20 & $(100 \%)$ & 40 & $(100 \%)$ \\
\hline Total & 20 & & & & & \\
\hline
\end{tabular}

Sumber: Data Penelitian (2015)

\section{(2) Pendidikan Terakhir}

Tingkat pendidikan responden pnelitian ini bervariasi, mulai dari lulusan Sekolah Dasar, Sekolah Menengah Pertama, Sekolah Menengah Akhir dan Perguruan Tinggi.Pada muara Way Tomu tingkat pendidikannya mayoritas adalah lulusan Sekolah Menengah Akhir (60\%), sama seperti responden pada lokasi muara Way Tomu, responden di lokasi muara Way Lela pun mayoritas tingkat pendidikannya lulusan Sekolah Menengah Akhir (55\%).

Apabila dilihat secara keseluruhan karakteristik responden menurut tingkat pendidikan yang ditempuhnya dapat disimpulkan bahwa secara umum responden pada kedua lokasi memiliki sikap yang tidak baik dalam melihat dampak dari buangan limbah domestik ke badan sungai.

\section{(3) Jumlah Anggota Keluarga}

Total jumlah anggota keluarga responden dalam penelitian ini adalah 182 orang dan rata-rata jumlah anggota keluarga adalah 4,6 orang per-rumah. Berdasarkan hasil penelitian diketahui bahwa jumlah anggota keluarga seluruh responden pada muara Way Tomu 60 orang dengan rata-rata jumlah anggota keluarga adalah 3,0 orang dan pada muara Way Lela 88 orang dengan rata-rata jumlah keluarga adalah 4,4 orang. Dari data tersebut dapat dilihat bahwa jumlah anggota keluarga per-rumah pada muara Way Lela relatif lebih tinggi dibandingkan dengan lokasi muara Way Tomu.
(4) Perilaku Responden dalam membuang Air Limbah Domestik dan Memanfaatkan BahanBahan yang Berpotensi Menurunkan Kualitas Air Sungai

Manusia sebagai makluk hidup dilengkapi dengan akal dan pikiran yang berfungsi untuk mengontrol dan mengendalikan perilakunya agar sesuai dengan yang dikehendakinya. Penelitian ini membagi bentuk operasional perilaku ini dalam tiga jenis yaitu:

a. Pengetahuan Responden tentang Pencemaran

Dari hasil wawancara 20 orang (100\%) responden sangat memahami tentang apa yang maksud dengan pencemaran (Tabel 4).

b. Sikap responden di sekitar lokasi muara Way Tomu dan Way Lela dalam membuang limbah domestik dan melakukan aktivitas

Sebagian besar responden $(82,5 \%)$ menyatakan setuju membuang limbah domestik ke sungai. Alasan responden bersikap demikian, dikarenakan: 1) Saluran yang digunakan untuk membuang air limbah rumah tangga arahnya ke sungai; 2) Kadar pencemaran air limbah rumah tangga dianggap rendah dan masih dapat ditolerir; 3) Cepat dan mudah; serta 4) Tidak tersedia lahan untuk mengelolah limbah domestik. Hal ini menjadi penyebab munculnya bahan-bahan pencemar yang menurunkan kualitas air sungai.

Namun dalam kesehariannya mereka tidak menunjukkan sikap yang menggambarkan pemahaman mereka tentang apa yang dimaksud dengan pencemaran. 
Tabel 4. Pengetahuan responden mengenai pencemaran sungai

\begin{tabular}{|c|c|c|c|c|c|c|}
\hline \multirow{3}{*}{ Keterangan } & \multicolumn{4}{|c|}{ Lokasi } & \multicolumn{2}{|c|}{ Total } \\
\hline & \multicolumn{2}{|c|}{ Muara Way Tomu } & \multicolumn{2}{|c|}{ Muara Way Lela } & \multirow{2}{*}{$\begin{array}{c}\text { Jumlah } \\
\text { orang }\end{array}$} & \multirow{2}{*}{$(\%)$} \\
\hline & Jumlah orang & $(\%)$ & Jumlah orang & $(\%)$ & & \\
\hline Tidak tahu & 0 & $(0 \%)$ & 0 & $(0 \%)$ & 0 & $(0 \%)$ \\
\hline Tahu & 20 & $(100 \%)$ & 20 & $(100 \%)$ & 40 & $(100 \%)$ \\
\hline Total & 20 & $(100 \%)$ & 20 & $(100 \%)$ & 40 & $(100 \%)$ \\
\hline
\end{tabular}

Sumber: Data Penelitian (2015)

Tabel 5. Pendapat responden terhadap pembuangan limbah domestik ke sungai

\begin{tabular}{lcccccc}
\hline \multirow{2}{*}{$\begin{array}{c}\text { Sungai Sebagai Tempat } \\
\text { pembuangan limbah } \\
\text { alternatif }\end{array}$} & \multicolumn{2}{c}{ Lokasi } & \multicolumn{2}{c}{ Total } \\
\cline { 2 - 5 } \multicolumn{1}{c}{ Muara Way Tomu } & $(\%)$ & Jumlah orang & $(\%)$ & Jumlah & \multirow{2}{*}{ orang } & $(\%)$ \\
\hline Tidak setuju & Jumlah orang & $(40 \%)$ & 9 & $(45 \%)$ & 17 & $(42 \%)$ \\
Setuju & 12 & $(60 \%)$ & 11 & $(55 \%)$ & 33 & $(82 \%)$ \\
\hline Total & 20 & $(100 \%)$ & 20 & $(100 \%)$ & 40 & $(100 \%)$ \\
\hline
\end{tabular}

Sumber: Data Penelitian (2015)

Responden yang menyatakan tidak setuju membuang limbah domestik ke sungai sebesar $(45,5 \%)$ tetap membuang. Alasan yang dikemukakan responden, antara lain: 1) Pembuangan limbah domestik ke sungai akan menyebabkan sungai menjadi kotor dan bau; 2) Mencemari sungai; dan 3) Limbah domestik mengganggu sumber air.

c. Tindakan dan kebiasaan responden di sekitar muara Way Tomu dan Way Lela dalam membuang limbah domestik

Tindakan responden dalam penelitian ini dilihat dari cara responden membuang limbah domestik yang meiliputi air buangan, sampah dari aktivitas mandi, cuci, kakus, dan aktivitas di sekitar muara sungai. Kebiasaan responden dilihat dari kebiasaan waktu mandi dan kebiasaan mencuci pakaian setiap minggu. Hal ini dikarenakan tidak tersedianya tempat penampungan sampah dan instalasi pengelolaan limbah yang disediakan di areal sungai, sehingga sungai menjadi tempat yang praktis dalam membuang limbah domestik.

\section{c.1. Pembuangan Air Limbah yang dilakukan}

\section{Responden.}

Responden yang posisi rumahnya berbatasan langsung dengan sungai, memiliki perilaku membuang air limbah rumah tangga ke sungai tanpa melalui saluran pembuangan. Artinya limbah yang dihasilkan dari rumah dan aktivitas hari-hari penduduk langsung ke sungai tanpa melewati saluran air.

Alasan yang dikemukakan responden dalam membuang limbah domestik ke sungai dikarenakan: 1) Dekat sungai; 2) Saluran yang memiliki arah langsung ke sungai; 3) Tidak tersedianya tempat sampah didekat muara sungai; 4) Lebih mudah; dan 5) Lebih cepat.

\section{c.2. Kebiasaan Waktu Mandi}

Pada lokasi muara Way Tomu, aktivitas mandi di sungai sudah tidak lagi dilakukan dikarenakan air sungai yang sudah tidak memungkinkan untuk digunakan, sedangkan pada lokasi muara Way Lela penduduk biasa melakukan aktivitas mandi karena kualitas air sungai masih memungkinkan untuk melakukan kebiasaan mandi.

\section{c.3. Kebiasaan Mencuci Pakaian}

Sama halnya dengan kebiasaan mandi pada lokasi muara Way Tomu aktivitas mencuci pakaian pun sudah tidak lagi dilakukan, sedangkan pada lokasi muara Way Lela aktivitas mencuci pakian masih menjadi kebiasaan rutin penduduk sekitar muara karena memudahkan responden dalam membuang sisa-sisa limbah cucian. Aktivitas mencuci pakaian paling banyak dilakukan oleh responden pada hari libur (hari minggu).

Parameter fisik, kimia dan biologi sungai Way Tomu dan Way Lelawilayah pesisir Kota Ambon

Pencemaran air pada sungai Way Tomu dan sungai Way Lela Wilayah Pesisir Kota Ambon khususnya pada bagian muara (hilir) sungai dapat terjadi sebagai akibat dampak bahan pencemar yang masuk ke badan sungai yang bersumber dari limbah domestik yang dibuang ke badan sungai maupun aktivitas penduduk sekitar muara sungai sehingga akan menurunkan kualitas air (fisik, kimia dan biologi) dan menyebabkan air sungai muara Way Tomu (MWT) dan muara Way Lela (MWL) menjadi tercemar.

\section{Sifat Fisik Air Muara Way Tomu dan Muara Way Lela}

Sifat fisik air merupakan salah satu sifat yang dapat digunakan untuk menilai kualitas air sungai. Maka dari empat titik pengambilan sampel pada setiap huara yang kemudian dikomposit, ada beberapa parameter yang dinilai antara lain: total dissolve solid (TDS), suhu dan total suspended solid (TSS) yang dapat dilihat pada Tabel 6. 
Tabel 6. Hasil analisis sifat fisik kualitas sampel air muara Way Tomy dan Way Lela

\begin{tabular}{|c|c|c|c|c|c|c|}
\hline \multirow[t]{2}{*}{ No } & \multirow[t]{2}{*}{ Parameter } & \multirow[t]{2}{*}{ Satuan } & \multicolumn{2}{|c|}{ Hasil Pengujian } & \multirow{2}{*}{$\begin{array}{c}\text { Kadar Max Yang } \\
\text { Dibolehkan }\end{array}$} & \multirow{2}{*}{ Keterangan } \\
\hline & & & MWT & MWL & & \\
\hline 1 & TDS & $\mathrm{mg} / \mathrm{L}$ & 184 & 175 & 1000 & K II \\
\hline 2 & Suhu & ${ }^{\circ} \mathrm{C}$ & 27,6 & 28,2 & Suhu udara $\pm 3^{0} \mathrm{C}$ & K II \\
\hline 3 & TSS & $\mathrm{mg} / \mathrm{L}$ & 4,8 & 6,3 & 50 & K II \\
\hline
\end{tabular}

Sumber: Data Hasil Analisis Laboratorium BTKL (2015)

\section{Sifat Kimia Air Muara Sungai Way Tomu dan Muara Way Lela}

Berdasarkan hasil analisis sifat kimia air muara Way Tomu (MWT) dan muara Way Lela (MWL), terdapat beberapa parameter bahan kimia diantaranya (deterjen, nitrat, nitrit, $\mathrm{pH}, \mathrm{BOD}, \mathrm{DO}$, amonia, fosfat, besi, minyak dan lemak, mangan, tembaga). Hal ini disajikan pada Tabel 7.

\section{Sifat Biologi Air Muara Sungai Way Tomu dan Way} Lela

Dalam penelitian yang dilaksanakan di kedua lokasi muara parameter biologi yang digunakan dalam menentukan kualitas air sungai ialah E. coli. Maka berdasarkan hasil analisis laboratorium terhadap sampel air kedua muara sungai dapat dilihat pada Tabel 8.

\section{Aktivitas Masyarakat di Sekitar Muara Way Tomu dan Muara Way Lela}

Berdasarkan hasil wawancara yang dilakukan terhadap responden didua lokasi penelitian, terlihat jelas bahwa perilaku masyarakat dalam membuang limbah domestik ke sungai dan melakukan aktivitas di sekitar sungai sangat beresiko terhadap menurunnya kualitas air sungai Way Tomu dan Way Lela. Hal ini dapat dilihat pada kedua lokasi penelitian dimana sungai menjadi tempat alternatif membuang limbah dan menyebabkan sungaitercemar dan menurunkan kualitas airnya.

\section{Kualitas Air Muara Way Tomu dan Muara Way Lela}

Pengujian kualitas air di Laboratorium Balai Teknik Kesehatan Lingkungan Ambon (2015), berdasarkan parameter fisik, kimia dan biologi di muara Way Tomu dan muara Way Lela Wilayah Pesisir Kota Ambon dan dibandingkan dengan Peraturan Pemerintah No 82 (2001). Kemudian dilihat bahan pencemar yang dominan yang melampaui standar baku mutu yang ditetapkan.

\section{Kualitas Fisik Air Muara Way Tomu dan Way Lela Kualitas fisik adalah salah satu sifat yang mempengaruhi menurunnya kualitas air, sehingga berdasarkan hasil analisis maka beberapa parameter fisik yang diuji antara lain; TDS, suhu, dan TSS. Tabel 7 menunjukkan bahwa parameter fisik, TDS, suhu dan TSS. Untuk TDS (total dissolved solids) banyak terdapat di daerah hilir, ini disebabkan karena pada daerah hilir banyak terjadi tumpukkan padatan atau zat- zat lain yang dibawa dari daerah hulu sungai, TDS pada muara Way Tomu dan muara Way Lela ialah $184 \mathrm{mg} / \mathrm{L}$ dan $175 \mathrm{mg} / \mathrm{L}$, dimana TDS pada muara Way Tomu lebih tinggi dari muara Way Lela.}

Tabel 7. Hasil analisis kualitas sampel air untuk sifat kimia di laboratorium BTKL Ambon (2015)

\begin{tabular}{|c|c|c|c|c|c|c|}
\hline \multirow{2}{*}{ No } & \multirow{2}{*}{ Parameter } & \multirow{2}{*}{ Satuan } & \multicolumn{2}{|c|}{ Hasil Pengujian } & \multirow{2}{*}{$\begin{array}{c}\text { Kadar Max Yang } \\
\text { Dibolehkan }\end{array}$} & \multirow[t]{2}{*}{ Ket } \\
\hline & & & MWT & MWL & & \\
\hline $\mathbf{A}$ & KIMIA & & & & & \\
\hline 1 & Deterjen & $\mu \mathrm{g} / \mathrm{L}$ & 746 & 835 & 200 & K II \\
\hline 2 & Nitrat $\left(\mathrm{NO}_{3}{ }^{-}\right)$ & $\mathrm{mg} / \mathrm{L}$ & 2,647 & 2,129 & 10 & K II \\
\hline 3 & Nitrit $\left(\mathrm{NO}_{2}^{-}\right)$ & $\mathrm{mg} / \mathrm{L}$ & 0,013 & 0,004 & 0,06 & K II \\
\hline 4 & $\mathrm{pH}$ & - & 7,94 & 8,13 & $6-9$ & K II \\
\hline 5 & BOD & $\mathrm{mg} / \mathrm{L}$ & 2,376 & 2,772 & 3 & K II \\
\hline 6 & COD & $\mathrm{mg} / \mathrm{L}$ & 10,67 & 16,00 & 25 & K II \\
\hline 7 & DO & $\mathrm{mg} / \mathrm{L}$ & 4,1 & 3,2 & $>4$ & $\mathrm{~K}$ II \\
\hline 8 & Amoniak & $\mathrm{mg} / \mathrm{L}$ & 1,732 & 1,977 & - & K II \\
\hline 9 & Fosfat $\left(\mathrm{PO}_{4} 3^{-}\right)$ & $\mathrm{mg} / \mathrm{L}$ & 0,0651 & 0,4631 & 0,2 & K II \\
\hline 10 & Besi & $\mathrm{mg} / \mathrm{L}$ & 1,94 & 0,13 & 3 & K II \\
\hline 11 & Minyak dan lemak & $\mathrm{mg} / \mathrm{L}$ & 2,39 & 1,37 & 10 & K II \\
\hline 12 & Mangan & $\mathrm{mg} / \mathrm{L}$ & 0,0 & 0,0 & 0,4 & K II \\
\hline 13 & Tembaga & $\mathrm{mg} / \mathrm{L}$ & 0,0 & 0,0 & 1 & K II \\
\hline
\end{tabular}

Sumber: Data Hasil Analisis Laboratorium BTKL Ambon (2015) 
Tabel 8. Hasil analisis sifat biologi kualitas sampel air di laboratorium

\begin{tabular}{|c|c|c|c|}
\hline \multirow[b]{2}{*}{ No } & \multirow[b]{2}{*}{ Parameter } & \multicolumn{2}{|c|}{ Hasil Pengujian } \\
\hline & & $\begin{array}{c}\text { MWT } \\
\mathrm{Jml} / 100 \mathrm{~mL}\end{array}$ & $\begin{array}{c}\text { MWL } \\
\text { Jml/100mL }\end{array}$ \\
\hline 1 & Bakteri E.coli & $1.898 .000) * * *$ & $1.866 .000)^{* * *}$ \\
\hline
\end{tabular}

Sumber: Data Penelitian (2015). Ket: $* * *=$ Batas baca alat ukur

Tabel 9. Parameter kimia yang dominan di muara way tomu dan muara way lela

\begin{tabular}{|c|c|c|c|c|c|}
\hline \multirow{2}{*}{ No } & \multirow{2}{*}{ Parameter } & \multirow{2}{*}{ Satuan } & \multicolumn{2}{|c|}{ Hasil analisis } & \multirow{2}{*}{ PP No. 82 tahun 2001} \\
\hline & & & MWT & MWL & \\
\hline 1 & Deterjen & $\mu \mathrm{g} / \mathrm{L}$ & 746 & 835 & 200 \\
\hline 2 & Dissolved Oxygen & $\mathrm{mg} / \mathrm{L}$ & 4,1 & 3,2 & $>4$ \\
\hline 3 & Fosfat & $\mathrm{mg} / \mathrm{L}$ & 0,0651 & 0,4631 & 0.2 \\
\hline
\end{tabular}

Untuk suhu terlihat bahwa pada muara Way Tomu dan muara Way Lela relatif rendah yakni $27,6^{\circ} \mathrm{C}$ dan $28,2^{\circ} \mathrm{C}$ nilai tersebut tidak melebihi batasan suhu maksimum yang dapat mengakibatkan kematian bagi mahluk hidup yakni sebesar $32,3^{\circ} \mathrm{C}$ sampai $32,5^{\circ} \mathrm{C}$ (Effendi, 2003), sehingga masih memenuhi syarat yang ditetapkan Peraturan Pemerintah No. 82 (2001), dimana suhu udara $\pm 3^{\circ} \mathrm{C}$. Fardiaz (1992) mengungkapkan bahwa kenaikan suhu air akan menimbulkan beberapa akibat diantaranya: jumlah oksigen terlarut dalam air akan menurun, kecepatan reaksi kimia meningkat, kehidupan ikan dan hewan air lainnya terganggu dan jika batas suhu yang mematikan terlampaui, ikan dan hewan air lainnya mungkin akan mati. Sedangkan pada parameter TSS, nilai uji pada muara Way Tomu 4,8 mg/L lebih rendah dibandingkan dengan muara Way Lela yaitu $6,3 \mathrm{mg} / \mathrm{L}$. Ketiga parameter fisik dari muara Way Tomu dan muara Way Lela ini masih masuk dalam syarat yang ditetapkan Peraturan Pemerintah no 82 tahun 2001 tentang Pengelolaan Kualitas Air dan Pengendalian Pencemaran Air untuk Kelas II.

\section{Kualitas Kimia Muara Way Tomu dan Muara Way Lela}

Kualitas kimia adalah sifat yang sangat berdampak besar untuk menurunnya kualitas air,maka dari penelitian yang dilakukan di dua lokasi yakni muara Way Tomu dan muara Way Lela terdapat tiga belas parameter kimia yang terdapat di dalam air Way Tomu dan Way Lela diantaranya: deterjen, nitrat $\left(\mathrm{NO}_{3}\right)$, nitrit $\left(\mathrm{NO}_{2}\right), \mathrm{pH}, \mathrm{BOD}, \mathrm{COD}, \mathrm{DO}$, amoniak, fosfat $\left(\mathrm{PO}_{4}\right)$, besi $(\mathrm{Fe})$, minyak dan lemak, mangan $(\mathrm{Mn})$, dan tembaga $(\mathrm{Cu})$.

Berdasarkan hasil analisis untuk tiga belas bahan kimia yang terdeteksi pada muara Way Tomu dan muara Way Lela terdapat tiga jenis bahan kimia yang sudah tidak memenuhi syarat baku mutu air yang ditetapkan Peraturan Pemerintah No. 82 (2001) tentang Pengelolaan Kualitas Air dan Pengendalian Pencemaran Air Kelas II. Ketiga bahan kimia tersebut yaitu: (deterjen, dissolved oxygen (DO) dan fosfat), hal ini menjadi penyebab menurunnya kualitas air sungai Way Tomu dan Way Lela.
Kandungan bahan kimia deterjen pada muara Way Tomu sebesar $746 \mathrm{mg} / \mathrm{L}$ dan untuk muara Way Lela sebesar $835 \mathrm{mg} / \mathrm{L}$ kedua nilai ini sudah melampaui baku mutu air yang ditetapkan Peraturan Pemerintah No. 82 (2001) sebesar 200 mg/L. Untuk kandungan DO pada muara Way Lela sebesar 3,1 mg/L kurang dari ketentuan minimun $4 \mathrm{mg} / \mathrm{L}$ namun pada muara Way Tomu kadar DO 4,1 mg/L masih dikatakan sesuai baku mutu yang ditetapkan sebesar $>4 \mathrm{mg} / \mathrm{L}$, dan untuk kandungan kimia fosfat nilai tertinggi yang sudah tidak sesuai dengan standar baku mutu air yang dibolehkan berada pada muara Way Lela, dimana kadar fosfat pada muara Way Lela sudah mencapai 0,4631 mg/L, sebaliknya kadar fosfat pada muara Way Tomu masih dikatakan sesuai dengan standar baku mutu yang dibolehkan. Hal ini dapat dilihat pada Tabel 9.

\section{Kualitas Biologi Muara Way Tomu dan Muara Way Lela}

Salah satu indikator penentu kualitas air adalah parameter biologi air dapat dinilai dari banyaknya kandungan mikroorganisme yang menjadi indikator terjadinya pencemaran. Parameter biologi yang diamati dalam penelitian ini adalah bakteri Escherichia coli. Nilai E. coli untuk Way Tomu 1.898.000)*** dan untuk Way Lela 1.866 .000$)^{* * *}$, kedua nilai ini sudah terlalu tinggi dan melebihi baku mutu yang ditetapkan Peraturan Pemerintah No. 82 (2001).

\section{Pengaruh Kepadatan Permukiman Terhadap Kualitas Air Muara Way Tomu dan Muara Way Lela}

Meningkatnya jumlah penduduk di suatu daerah berdampak kepada kepadatan permukiman, hal ini menyebabkan jumlah limbah rumah tangga ataupun limbah domestik menjadi meningkat, maka menyebabkan pencemaran. Hal ini dapat dilihat di muara Way Tomu dan Way Lela, dimana di muara Way Tomu tingkat kepadatan permukiman lebih tinggi dari muara Way Lela sehingga berpengaruh terhadap kualitas air, karena volume limbah yang dibuang ke badan sungai lebih besar. 


\section{Bahan Pencemar Dominan pada Muara Way Tomu dan Muara Way Lela}

Berdasarkan tiga kualitas (fisik, kimia dan biologi) yang diteliti di muara Way Tomu dan muara Way Lela untuk mengetahui bahan pencemar yang dominan. Hasil analisis ditemukan bahan pencemar dominan di kedua muara yakni indikator kimia (deterjen, DO, fosfat) dan indikator biologi (E. coli). Keempat indikator tersebut sudah melampaui batas baku mutu yang ditetapkan Peraturan Pemerintah No. 82 (2001) tentang Pengelolaan Kualitas Air dan Pengendalian Pencemaran Air Kelas II, dapat dilihat pada Tabel8 dan9.

\section{Deterjen}

Berdasarkan hasil analisis laboratorium nilai parameter Deterjen untuk kedua lokasi penelitian yakni muara Way Tomu $(746 \mu \mathrm{g} / \mathrm{L})$ dan muara Way Lela (835 $\mu \mathrm{g} / \mathrm{L})$. Nilai kedua muara tersebut sudah melebihi syarat baku mutu air yang ditetapkan Peraturan Pemerintah no 82 tahun 2001 sebesar $(200 \mu \mathrm{g} / \mathrm{L})$, sehingga menurunkan kualitas kedua air di muara sungai yang diteliti. Dibandingkan dengan penelitian sebelumnya dimuara Way Tomu nilai deterjen lebih rendah 1,87 $\mu \mathrm{g} / \mathrm{L}$ (Titaley, 2014) sedangkan nilai deterjen pada muara Way Tomu lebih tinggi dan menyebabkan tercemarnya sungai dan menurunnya kualitas air sungai. Meningkatnya kandungan deterjen di muara sungai disebabkan oleh beberapa faktor yaitu: 1) semakin tinggi buangan limbah deterjen ke badan sungai; 2) aktifitas mencuci dan mandi disungai; dan 3) pemukiman padat disekitar muara. Semua ini menyebabkan meningkatnya kadar deterjen yang melebihi baku mutu air sehingga mempengaruhi menurunnya kualitas air di muara Way Tomu dan muara Way Lela Wilayah Pesisir Kota Ambon. Hal lain yang diakibat oleh buangan limbah deterjen ke sungai yaitu dapat mengakibatkan sifat fisik air berupa TDS dan TSS tergolong buruk.

Deterjen yang digunanakan dalam aktivitas penduduk sekitar muara antara lainnya jenis deterjen krim dan bubuk, yang digunakan untuk mencuci dan sebagainya, sehingga sisa-sisa deterjen yang digunakan dibuang langsung ke badan sungai. Deterjen yang selama ini digunakan untuk mencuci pakaian sebenarnya merupakan hasil sampingan dari proses penyulingan minyak bumi yang diberi berbagai tambahan bahan kimia seperti fosfat, silikat, bahan pewarna, dan bahan pewangi. Sehingga berdasarkan hasil penelitian yang dilakukan di kedua muara, diketahui deterjen ternyata mempunyai efek buruk terhadap lingkungan, yaitu sulit diuraikan oleh mikroorganisme, sehingga sisa limbah deterjen yang dihasilkan setiap hari oleh rumah tangga akan menjadi limbah berbahaya yang mengancam stabilitas lingkungan hidup.

Limbah deterjen yang mengandung fosfat mengakibatkan terjadinya eutrofikasi yang merupakan proses alamiah yang terjadi di perairan yang terkontaminasi oleh bahan nitrat dan fosfat akibat aktivitas manusia disekitar muara. Oleh karena itu deterjen juga merupakan sumber penyebab eutrofikasi yang perlu mendapatkan perhatian khusus, karena masalah yang serius akibat eutrofikasi ditimbulkan oleh petumbuhan alga sel tunggal secara hebat, proses dekomposisi dari sel yang mati akan mengurangi oksigen terlarut dampak lain dari eutrofikasi ialah rusaknya habitat untuk kehidupan berbagai spesies ikan dan invertebrata, kerusakan habitat akan menyebabkan berkurangnya biodiversitas di habitat akuatik dan spesies lain dalam rantai makanan, konsentrasi oksigen terlarut turun sehingga beberapa spesies ikan dan kerang tidak toleran untuk hidup, dan rusaknya kualitas areal yang mempunyai nilai konservasi/cagar alam margasatwa atau ekowisata. Umumnya deterjen mengandung surfaktan yang berfungsi sebagai bahan pembasah yang menyebabkan turunnya tegangan permukaan dari air sungai, surfaktan atau bahan pembasah merupakan bahan organik yang berperan sebagai bahan aktif pada deterjen, sabun, dan shampoo (Effendi, 2003). Selain surfaktan deterjen juga mengandung builder (bahan pembentuk). Builder berfungsi meningkatkan efisiensi pencuci dari surfaktan dengan cara menon-aktifkan mineral penyebab kesadahan air. Air sungai yang tercemar limbah deterjen berakibat buruk bagi flora dan fauna yang hidup di sungai. Ikan dan tumbuhan yang ada di sungai dapat mati karena ekosistem tempat hidup mereka tercemar. Zat yang terdapat dalam limbah deterjen dapat memacu pertumbuhan eceng gondok dan gulma air sehingga dapat mengakibatkan ledakan jumlah tanaman tersebut. Hal ini akan berdampak pada kualitas air dan ikan-ikan menjadi sulit untuk bertahan hidup. Penelitian juga menunjukkan bahwa deterjen mempunyai pengaruh terhadap flora dan fauna yang hidup di sungai. Limbah deterjen yang tidak dapat diurai dalam waktu yang singkat ini menyebabkan polusi udara karena baunya yang tidak sedap. Menurut Frick (2007), deterjen terurai dalam hitungan minggu hingga bulanan sedangkan persyaratan ekolabel memberikan jangka waktu peruraian limbah deterjen di lingkungan alam hanya dua hari. Selain itu deterjen dalam air buangan dapat meresap ke air tanah atau sumur-sumur di masyarakat. Air yang tercemar limbah deterjen tidak baik bagi kesehatan karena dapat menyebabkan kanker. Kanker ini diakibatkan oleh menumpuknya surfaktan di dalam tubuh manusia. Linear Alkilbenzena Sulfona jenis deterjen ini mampu dibiodegradasi di bawah kondisi aerobik dalam media mengandung air, dan sebagian besar dapat dihilangkan dengan pengelolaan limbah cair, namun sejumlah fraksi penting (sebanyak 20-25\%) terimobilisasi dalam limbah padat dan persisten dalam kondisi aerobik (Rubiatadji, 1993).

\section{(1) Dissolved Oxygen}

Hasil analisis menunjukan nilai dissolved oxygen (DO) pada sampel air Muara Way Lela sebesar 3,2 $\mathrm{mg} / \mathrm{L}$, nilai ini masih lebih kecil dari standar baku mutu dan tidak sesuai dengan persyaratan baku mutu air yang ditetapkan PP No. 82 (2001) yakni >4 mg/L, dengan demikian menurunnya kualitas air sungai. Jumlah oksigen terlarut yang ada dalam air dipengaruhi oleh suhu, tekanan parsial gas-gas baik yang ada di udara 
maupun di air, kadar garam serta adanya bahan-bahan yang mudah teroksidasi. Tinggi rendahnya kandungan oksigen terlarut dalam suatu perairan menunjukkan tingkat kesegaran suatu perairan. Nilai DO semakin tinggi menggambarkan suatu badan perairan semakin baik karena air tersebut masih murni yang jumlah oksigen terlarut masih tinggi.

Semakin banyak jumlah DO maka kualitas air semakin baik, jika kadar oksigen terlarut yang terlalu rendah akan menimbulkan bau yang tidak sedap akibat degradasi anaerob yang mungkin saja terjadi. Satuan oksigen terlarut dinyatakan dalam presentase saturasi. Oksigen terlarut dibutuhkan oleh semua jasad hidup untuk bernapas, proses metabolisme atau pertukaran zat yang kemudian menghasilkan energi untuk partumbuhan dan pembiakan. Disamping itu, oksigen juga dibutuhkan untuk oksidasi bahan-bahan organik dan anorganik dalam proses aerobik. Sumber utama dalam perairan berasal dari suatu proses difusi dari udara bebas dan hasil fotosintesis organik yang hidup dalam perairan tersebut (Salmin, 2000).

\section{Fosfat $\left(\mathrm{PO}_{4}\right)$}

Fosfat diketahui sebagai bahan kimia yang memicu pertumbuhan alga tak terkendali (ganggang) yang menutup permukaan air dan penyebab eutrofikasi (Morse et al., 1993). Berdasarkan hasil analisis untuk muara Way Tomu dan muara Way Lela terlihat pada Tabel 9, nilai $\mathrm{PO}_{4}$ pada muara Way Lela lebih tinggi dibandingkan dengan nilai $\mathrm{PO}_{4}$ pada muara Way Tomu hal ini menyebabkan nilai $\mathrm{PO}_{4}$ pada muara Way Lela sudah melewati syarat yang ditetapkan Peraturan Pemerintah No. 82 (2001) yakni $0,2 \mathrm{mg} / \mathrm{L}$, hal ini disebabkan pada sekitar muara Way Lela terdapat banyak aktivitas penduduk yang membuang limbah yang mengandung fosfat ke dalam badan sungai. Salah satu contohnya kegiatan penduduk mencuci pakaian dengan menggunakan deterjen. Namun demikian fosfat tidak beracun bagi hewan air dan tidak mengganggu kesehatan manusia (Fardiaz, 2003). Selain itu dapat berasal dari atmosfer dan bersama dengan curah hujan masuk kedalam perairan. Senyawa fosfat dalam perairan berasal dari sumber alami seperti erosi tanah, buangan dari hewan dan pelapukan tumbuhan, dan dari laut sendiri.

Sungai menjadi sumber fosfat karena sungai membawa hanyutan sampah maupun sumber fosfat daratan lainnya, sehingga sumber fosfat dimuara sungai lebih besar dari sekitarnya. Keberadaan fosfat di dalam air akan terurai menjadi senyawa ionisasi, fosfat diabsorpsi oleh fitoplankton dan seterusnya masuk kedalam rantai makanan. Senyawa fosfat dalam perairan berasal dari sumber alami seperti erosi tanah, buangan dari hewan dan pelapukan tumbuhan, dan dari laut sendiri. Peningkatan kadar fosfat dalam air laut, akan menyebabkan terjadinya ledakan populasi (blooming) fitoplankton yang akhirnya dapat menyebabkan kematian ikan secara massal. Kandungan ataupun residu fosfat di perairan merupakan indikasi tingkat kesuburan perairan dan memicu terjadinya pengkayaan perairan.
Menurut Morse et al. (1993) sumber fosfor penyebab eutrofikasi $10 \%$ berasal dari proses alamiah di lingkungan air itu sendiri (background source), $7 \%$ dari industri, $11 \%$ dari detergen, $17 \%$ dari pupuk pertanian, $23 \%$ dari limbah manusia, dan yang terbesar, $32 \%$, dari limbah peternakan. Paparan statistik di atas menunjukkan bagaimana besarnya jumlah populasi dan beragamnya aktivitas masyarakat modern menjadi penyumbang yang sangat besar bagi lepasnya fosfor ke lingkungan air. Masalah eutrofikasi menggambarkan bagaimana aktivitas manusia di daratan dapat menurunkan derajat mutu perairan khususnya muara sungai.

\section{KESIMPULAN}

Berdasarkan hasil penelitian dan pembahasan di atas dapat ditarik beberapa kesimpulan sebagai berikut: 1) Bahan pencemar dominan di muara Way Tomu dan Way Lela adalah parameter kimia dan biologi; 2) Kadar deterjen (muara Way Tomu $(746 \mu \mathrm{g} / \mathrm{L})$ dan Way Lela $(835 \mu \mathrm{g} / \mathrm{L})$, DO (muara Way Tomu $4.1 \mathrm{mg} / \mathrm{L}$ ) dan fosfat (muara Way Lela $0,4631 \mathrm{mg} / \mathrm{L}$ ) menunjukan bahwa nilai parameter tersebut telah melampaui nilai baku mutu air sesuai Peraturan Pemerintah No 82 (2001) tentang Pengelolaan Kualitas Air dan Pengendalian Pencemaran Air Kelas II. Begitu pula kadar E. coli telah melampaui nilai baku mutu; dan 3) Pengaruh kepadatan permukiman dan perilaku masyarakat di sekitar muara Way Tomu dan Way Lela berbeda dalam membuang limbah domestik ke badan sungai, dimana kedua lokasi permukiman yang berbeda berpengaruh terhadap pencemaran yang pada akhirnya mengakibatkan menurunnya kualitas air di kedua muara yang diteliti. Tingginya kepadatan permukiman telah menyebabkan jumlah limbah domestik yang dibuang ke badan sungai juga semakin tinggi.

\section{DAFTAR PUSTAKA}

Effendi, H. 2003. Telaah Kualitas Air bagi Pengelolaan Sumber Daya dan Lingkungan Perairan. Yogyakarta: Kanisius.

Fardiaz, S. 1992. Polusi Air dan Udara. Yogyakarta: Kanisius.

Frick, H. 2007. Dasar-Dasar Aristekstur Ekologis. Bandung: ITB.

Greenberg, A.E. 1995. Standard Methods for the Examination of Water and Wastewater, 19th edition. American Public Health Association (APHA). APHA, Washington DC.

Kristanto, P. 2002. Ekologi Industri. Yogyakarta: Penerbit Andi.

Morse, G.K., J.N. Lester, and R. Perry. 1993. The Economic and Environment Impact of Phosphorus Removal from Wastewater in the European Community. Department for Environment, Food and Rural Affairs. AGRIS FAO.

Soemarwoto, O. 1991. Ekologi Lingkungan Hidup, dan Pembangunan. Jakarta: PT. Bina Aksara. 
Peraturan Pemerintah No. 82. 2001. Tentang Pengelolaan Kualitas Air dan Pengendalian Pencemaran Air Kelas II.

Rubiatadji. R. 1993. Penurunan Kadar Deterjen (Alkyl Benzene Sulphonate) Dalam Air Degan Proses Adsorpsi Karbon Aktif. Tugas Akhir. Program Studi Teknik Lingkungan, ITS, Surabaya.

Salmin. 2000. Kadar Oksigen Terlarut di Perairan Sungai Dadap, Goba, Muara Karang dan Teluk Banten. Dalam: Foraminifera Sebagai Bioindikator Pencemaran, Hasil Studi di Perairan Estuarin Sungai Dadap, Tangerang (D.P.
Praseno, R. Rositasari, dan S.H. Riyono, eds.) P3O - LIPI, hal 42-46.

Suriawira, U. 1986. Mikrobiologi Air dan Dasar-dasar Pengolahan Buangan Secara Biologis. Bandung: Alumi.

Titaley. H. 2014. Kualitas Air Sugai Akibat Buangan Sampah Domestik Ke Alur Sungai Wai Tomu Kota Ambon. Skripsi. Fakultas Pertanian. Universitas Pattimura.

Wisnu. A. 1995. Dampak Pencemaran Lingkungan. Yogyakarta: Penerbit Andi Offset. 